\title{
過重労働者の健康リスクマネジメントのためのアクション チェックリストの活用と評価
}

中尾 智 ${ }^{1,2}$, 川瀬 洋平 2,3 , 新見 $\quad$ 亮輔 $^{2}$, 山下 真紀子 ${ }^{2}$, 三觜 $\quad$ 明 4 , 福田 華名子 ${ }^{5}$, 川波 祥子 ${ }^{2}$, 廣 尚典 ${ }^{6}$, 堀江 正知 ${ }^{2}$

1 株式会社アルバック 人事部 健康推進室

2 産業医科大学 産業生態科学研究所 産業保健管理学研究室

3 三菱化学株式会社 人事部 健康開発センター

4 中央労働災害防止協会 健康確保推進部 人材開発課

5 東京商工会議所 産業政策部

6 産業医科大学 産業生態科学研究所 精神保健学研究室

要旨：本研究では, 長時間労働者に対する医師の面接指導を含めた過重労働対策の 体制を効果的に構築するためのツールとして開発された「過重労働者の健康 リスクマネジメントのためのアクションチェックリスト」(以下, ACL)を用い て, 過重労働対策をテーマとしたセミナーでの試用(以下，セミナー調査）お よび小規模事業場を中心とした 40 社を対象に介入研究 (以下, 介入調査)を行 い, その有用性の評価を試みた。介介調査では, 回収率が不十分だったこと, 法 令の適用前であったこと, 介入期間が短かった可能性があったことなどの要 因により,介入効果は得られなかった。一方で, セミナー調査では, 約 8 割の参 加者からACLの使用方法が理解でき, 事業場に戻ってからも利用できそうで あるとした評価を得た。また, 過重労働対策で遭遇し得る仮想の事例に対し ても, ACLの利用によって解決方法が検討しやすくなる可能性が示唆された。

キーワード：長時間労働, 過重労働, 産業保健, アクションチェックリスト.

( 2008 年 5 月 29 日 受付, 2008 年 9 月 18 日 受理)

はじめに

平成17 年に労働安全衛生法 (以下, 安衛法) が改正され, 過重労働対策の推進を目的とし て, 長時間労働者などに対する医師による面 接指導(以下, 面接指導) が新たに事業者の義 務として規定された。この規定によれば, 面
接指導は, 労働者の労働時間および労働者の 自覚症状と申出を基準にして実施される。し たがって, 事業場に扔いて面接指導を適切に 行うためには, 健康に障害を生じうる労働時 間の判断や自覚症状の適切な把握, 面接を申 し出る労働者のための空口といった面接指導 体制が必要となる。通常, 事業場において, こ 
れらの体制を整える役割は，産業医，保健師， 衛生管理者, 総務人事担当者, その他産業保健 業務に従事する者(以下, 産業保健従事者) が 担っている.

安衛法改正に伴い, 関係省令が改正され, 関 連する行政通達や手引書も作成され，事業場の 産業保健従事者が法規を正しく理解し, その上 で過重労働対策を推進することが期待されて いる。 しかし, 小規模事業場などでは, 産業保 健活動に注力できる人員が少ないことなどを 理由に面接指導体制の整備が進んでいないと いうことが指摘されている $[1,2]$. 常時使用す る労働者が50 人未満の小規模事業場において は, 平成20 年 4 月 1 日より面接指導の実施が義 務化される。

このような背景から, 小規模事業場をはじ めとする面接指導の体制が未整備な事業場に, 過重労働対策の一環としての面接指導体制を 構築する際に活用できるッールとして「過重 労働者の健康リスクマネジメントのためのア クションチェックリスト」(以下, $\mathrm{ACL})$ が開発 された $[3,4]$ 。 そこで, 今回我々は, ACLが事 業場における面接指導体制の構築および改善 に有用なツールとなり得るか否かについて評 価することを目的に本調查を実施した。

\section{対象と方 法}

ACLの評価のために二種類の研究を実施し た。まず，過重労働対策に関係する産業保健 従事者を対象としたセミナーの教材として ACLを使用して，面接指導の体制を構築する 上でしばしば遭遇する仮想課題に対する改善 策の立案に与える影響およびACLの使用感を 調查した(以下,セミナー調查)。次に, 中小規 模の事業場の人事労務担当者を会員とする勉 強会に参加した事業場を, ACLを配布する群 (介入群)および配布しない群(非介入群)に分 け, ACLが事業場の面接指導の体制に与える 影響を評価した(以下, 介入調査)。以下, それ ぞれの研究方法を具体的に述べる。
1. セミナー調査

平成 19 年 8 月 28 日に中央労働災害防止協会 で行われた「過重労働対策・メンタルヘルス対 策セミナー」に打ける三つのテーマ(過重労 働・メンタルヘルス対策と労働安全衛生法, 過重な労働による健康障害を防ぐ, ストレス 軽減対策への検討) の中の一つのテーマ(スト レス軽減対策への検討）の中でACLを教材と して使用した。セミナー参加者へは,「ストレ 久軽減対策への検討」のテーマでは新たに開 発されたACLを用いた研修を行うことを会場 で説明した後,グループワーク形式で進めら れた。 まず，参加者 31 人を 4 グループに分け た．検討する課題は, Table 1 にある4 事例を準 備し，各グループに一つずつ割り当てた，提 示された事例に対し，その問題点および改善 策を約 20 分間の討論後(以下, ACL配布前), ACLを配布し, ACLの使用方法を説明後, さら にACLを使用しながら約25 分間事例に対す る討論を追加した(以下, ACL配布後)。グル ープワーク討論の内容は, ACL配布前と配布 後に回収し, 問題点の抽出項目数および改善 策の提案項目数の変化を比較し, 提案内容に ついても検討を行った。さらに, セミナー終 了後にアンケート調查を行った。調査内容は, 所属組織, 部門, 所有資格, セミナー参加目的, 三テーマそれぞれの有益性(以下, 七ミナー基 礎調査) および面接指導の実施状況, 産業医な どの選任状況, ACLの使用感 (以下, ACL使用 感調查など）とした。また, 回答者の事業場を 想定して実際にACLを使用してもらい, その 結果を集計した。

\section{2. 介入調査}

東京商工会議所に入会し, 労働安全衛生に 関する勉強会へ定期的に参加している，産業 保健活動に比較的熱心な中小規模の事業場で ある計40 事業場を対象としたＡCLの配布を 予定した会議に出席した事業場を介入群 (27 事業場)，偶然欠席した事業場を対照群 (13 事 業場) とした。平成19 年10 月下旬に第一回の 
Table 1.グループワークで使用した 4 事例

\begin{tabular}{|c|c|}
\hline 事例番号 & 事 \\
\hline & 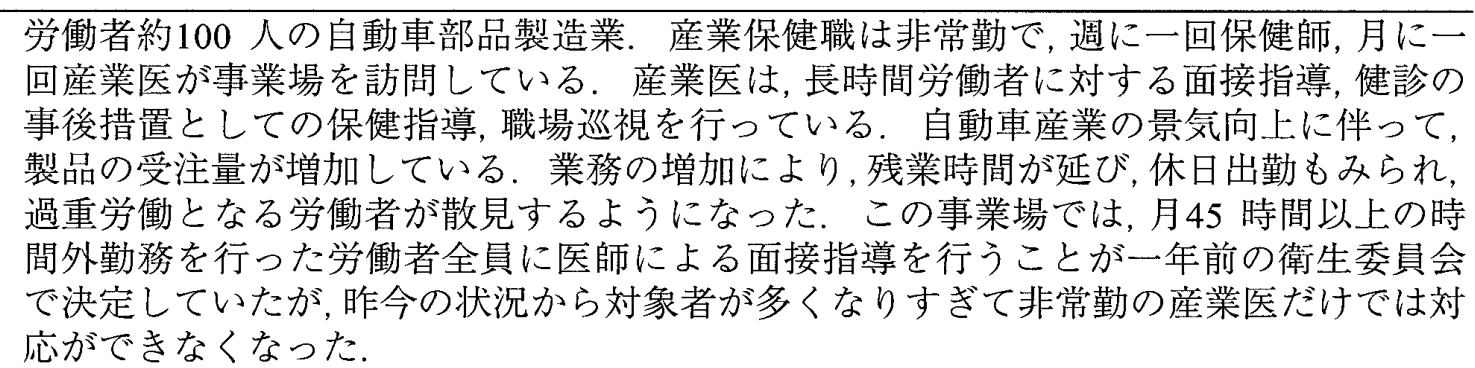 \\
\hline
\end{tabular}

2. 労働者約 120 人の情報通信業(その他, 派遣労働者 80 名)。業務は, 工場内の大型プラ ントの制御システムをプログラムし，客先に納めることである。産業保健職は非常 勤で，月に二回保健師，月に一回産業医が事業場を訪問し，健診の事後措置としての 保健指導, 長時間労働者に対する面接指導, 衛生委員会の出席, 職場巡視を行ってい る.もともと必要最低ラインの人員でチームを組んでプログラムを行っているため, 納品日やプログラムの試運転予定日が近づいてくると深夜までの残業や休日出勤が 增え, 年中長時間労働者が散見される。 また, 36 協定により,一ヶ月 100 時間, 三ヶ月 175 時間, 一年720 時間を超えてはならないこととされており, 労働者が, イントラネ ット上に自らの出社時間掞よび退社時間を毎日入力して労働時間を管理している. とある月の衛生委員会で産業医が, 書類上の残業時間と面接指導時に聴取した残業時間 が大きく乘離していること, 職場巡視時に面接指導の結果や記録が事務所内に散乱して いることを意見した。

3. 労働者約 500 人の製造業. 大型鉄鋼製品を工場で製造し, 納品先の現地で据付作業を行 うことが業務の中心である。産業保健職は, 常勤の保健師と産業医がそれぞれ一名い る。工事が集中する繁忙期には, 残業時間が長くなり, 事業場で設定された過重労働の 基準(月 80 時間以上の時間外労働)を超える労働者も多くなる．事業場で設けた基準を 超えた労働者は, 全員産業医面談を行うこととしているが, 過重労働者の多くは現地で の工事のため出張しており, 約半分は面談を欠席している現状にある.

4. 労働者約 150 人の金融業. 産業保健職は, 保健師はいないが, 非常勤の産業医が一名おり, 月に一回事業場を訪問している. 貸付担当部署の部長が, 心筋梗塞になり, 一命はとりと めたものの3週間入院することとなった。管理職の立場であるため労働時間の管理はし ていなかったが, 平日は22 時以降まで在社し残務整理を行い, 土日もほとんど出勤してい たことが部署内の労働者の話からわかった。

同事業場では, 衛生委員会で月 100 時間以上の時間外勤務を行った労働者に対し, 翌月の 産業医訪問日に, 医師による面接指導を行うことが定められ, 実施していたが, 課長職以 上の職位に対して行ったことはなかった。 
アンケート調査(以下, 第一回調査)を行い, 事 業場の規模, 業種, 産業保健職の選任状況掞よ び面接指導の実施状況などの情報を収集した 第一回調査の後, 介入群にのみACLを配布し, 約一カ月後に第二回のアンケート (以下, 第二 回調査)を実施した，第二回調査の内容は,介 入期間前後に生じた事業場の面接指導の実施 状況の変化を比較するため, 第一回と同様と した。面接指導の実施状沉は，「面接指導の実 施状況および体制の準備状況」「労働時間に よる面接指導等の対象者の選定基準」「労働 時間以外による面接指導等の対象者の選定基 準」および「面接指導に準ずる措置の実施内 容」の四項目について調査を行った。また，第 一回調査の後, 両群には, 従業員 50 人未満の 小規模事業場にも面接指導の実施義務が平成 20 年 4 月 1 日より適用されることを情報提供 するためにA4 版一頁の資料を配布した。い ずれのアンケート調查も郵送法またはFAXで 行い, 回答のない事業場へは東京商工会議所 の衛生担当部署から催促を行った。第一回調 査と第二回調査の結果を関連付け，かつ事業 場のプライバシーに配慮するために次の手順 で回収およびデー夕入力を行った。アンケー 卜は記名式で東京商工会議所へ送付後, 東京 商工会議所によるデー夕入力段階で事業場名 はID化され，我々の研究班へ送付された。事 業場名とIDの対応表は, 東京商工会議所の担 当者による保管とした。

\section{結果}

1. セミナー調査

セミナーの出席者数は 31 人であった。 セミ ナー基礎調查抢よびACL使用感調查の回収率

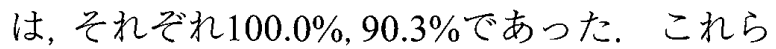
のアンケート調查の結果をTable 2 に示した。 事業場または自治体からの参加が多く24人 (77.4\%), 所属部署の内訳は, 健康管理·診療 10 人 $(41.7 \%)$, 安全·衛生 5 人 $(20.8 \%)$, 人事·労務
5 人 $(20.8 \%)$ の順で多かった. 出席者 31 人中, 保健師·看護師・助産師の資格を持つ人は 12 人 $(38.7 \%)$, 衛生管理者の資格を持つ人は 13 人 $(41.9 \%)$ であった。 セミナー受講の目的は, 「事業場全体での活動推進のため」と回答した 人は 16 人 $(51.6 \%)$,「自己啓発のため」と回答 した人は7 人 $(22.6 \%)$ であった。各テーマの 有益性を 1 (有益ではない) 4(大変有益であ る)の4 段階スケールで測定した結果, ACLを 使用した時間带の評価は $3.2 \pm 0.81$ (平均士標 準偏差)で, ACLを使用しなかった二つのテー マと反復測定分散分析で多重比較した結果, $5 \%$ 水準で有意差を認めなかった。 セミナー の参加目的が自己啓発のため」であった参加 者のACLを使用したテーマに対する評価は平 均2.71 00.95 であり, 参加目的が「事業場全体 での活動推進のため」である参加者では平均 $3.50 \pm 0.63$ であった(Table 3).

事例に関する問題点抽出および改善提案項 目の数はACL配布後は配布前に比較して，問 題点で平均 0.5 項目, 改善案で平均 1.5 項目増 加した (Fig. 1). ACL配布後に提案された改 善案には,「月 45 時間以上の時間外労働者に は保健師による面談を活用する」, 「面接指導 の結果の保管方法について体制を確立する」, 「面接指導の結果を職場にフィードバックす る手順について定める」といった, ACLの項目 に準じた内容が認められた。

ACLの使用感に関するアンケートでは, 過 重労働対策の体制作りのポイントが理解で きた」または「どちらかといえば理解できた」 とする回答は $92.9 \%$, 自身の事業場に戻って から「利用できそう」または「少し利用できそ う」とする回答は75\%であったＡCLの試用 の結果, 18個のアクション項目のうち「できて いる」割合が高かった項目は,「面接指導の記 録は個人情報として扱う」(78.6\%),「面接指 導の記録の保管方法を決める」(75.0\%) であ り、「不十分である」割合が高かった項目は, 「労働時間以外の判断基準を決める」(42.9\%), 
Table 2. セミナー調査のアンケート結果

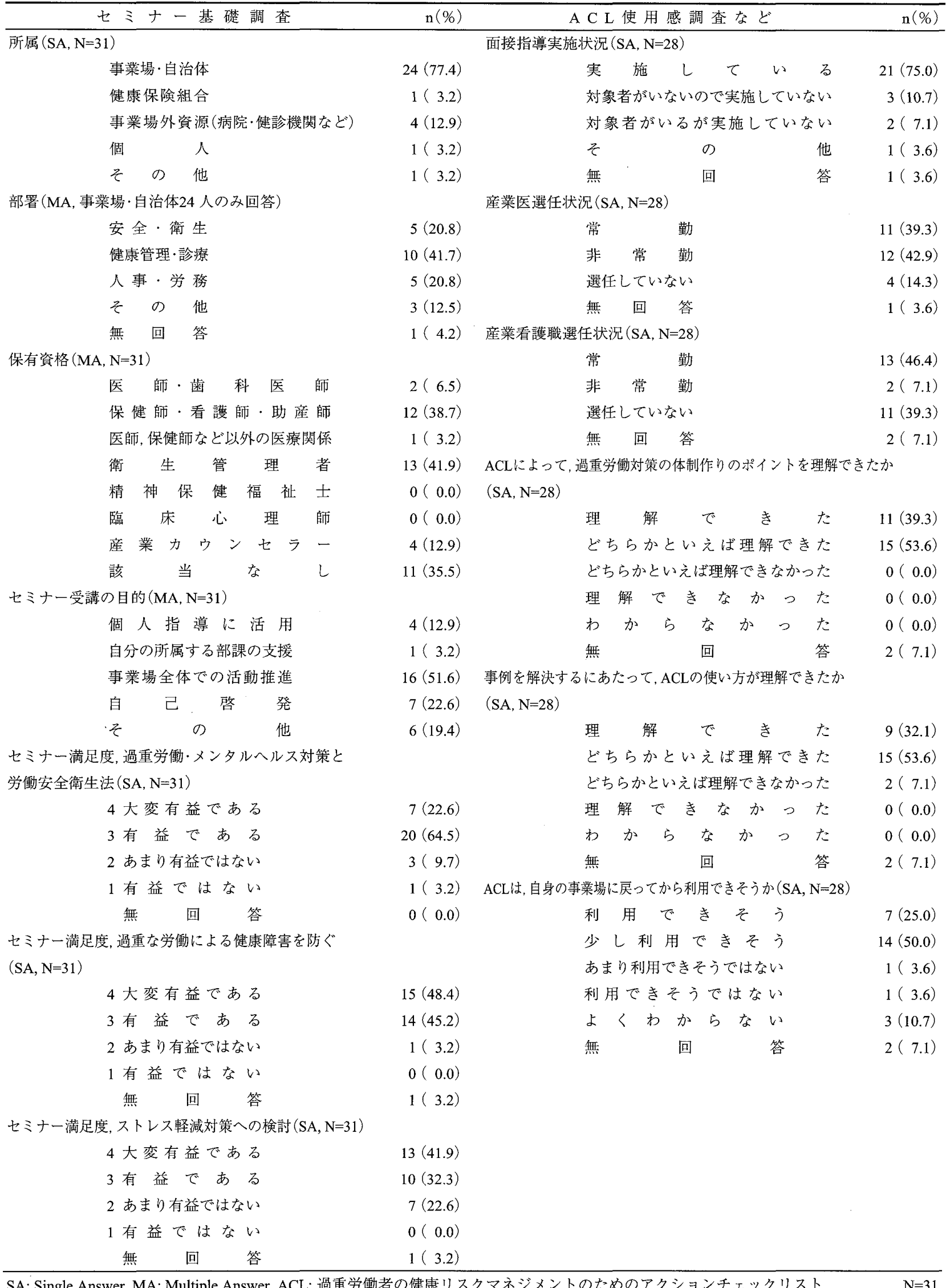


Table 3. セミナーの有益性についての評価, 参加理由別

Mean $\pm \mathrm{SD}$

セミナー参加理由

過重労働・メンタルヘ 過重な労働による健 ルス対策と労働安全康障害を防ぐ(産業医 衛生法 (法令と判例に 関する講義)

\begin{tabular}{|c|c|c|c|c|}
\hline 個人指 導に活用 & 4 & $2.75 \pm 0.50$ & $3.75 \pm 0.50$ & $3.00 \pm 0.82$ \\
\hline 自分の所属する部署の支援 & 1 & 3.00 & 3.00 & 3.00 \\
\hline 事業場全体での活動推進 & 16 & $3.00 \pm 0.73$ & $3.56 \pm 0.51$ & $3.50 \pm 0.63$ \\
\hline 啓 & 7 & $3.29 \pm 0.49$ & $3.14 \pm 0.69$ & $2.71 \pm 0.95$ \\
\hline の & 5 & $3.33 \pm 0.82$ & $3.60 \pm 0.55$ & $3.40 \pm 0.89$ \\
\hline
\end{tabular}

ストレス軽減対策への 検討(ACLを利用した セミナー)

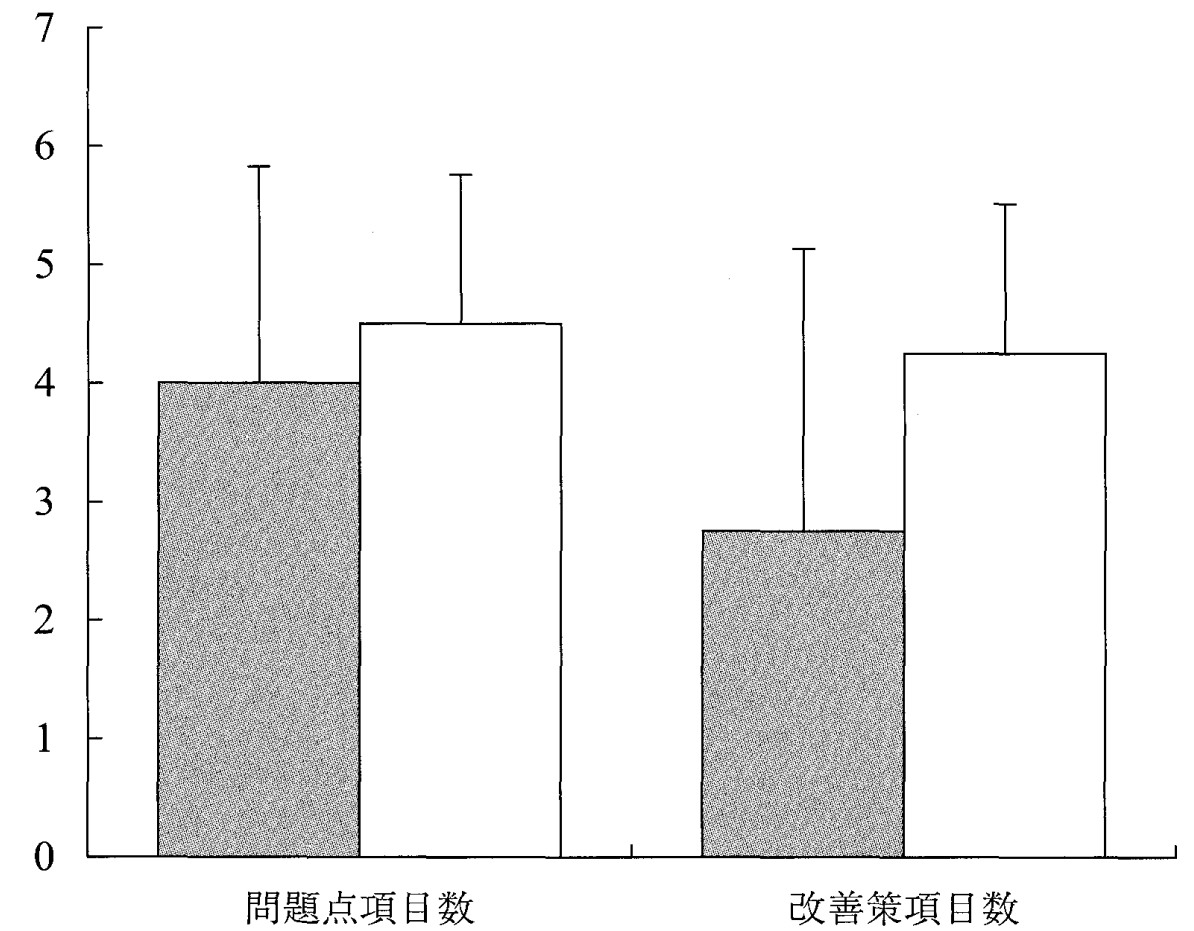

Fig. 1. ACL使用前後別 $(\mathrm{N}=4$ グループ) 事例の問題点および改善策項目数 の変化.

: ACL使用前, $\square$ : ACL使用後. 


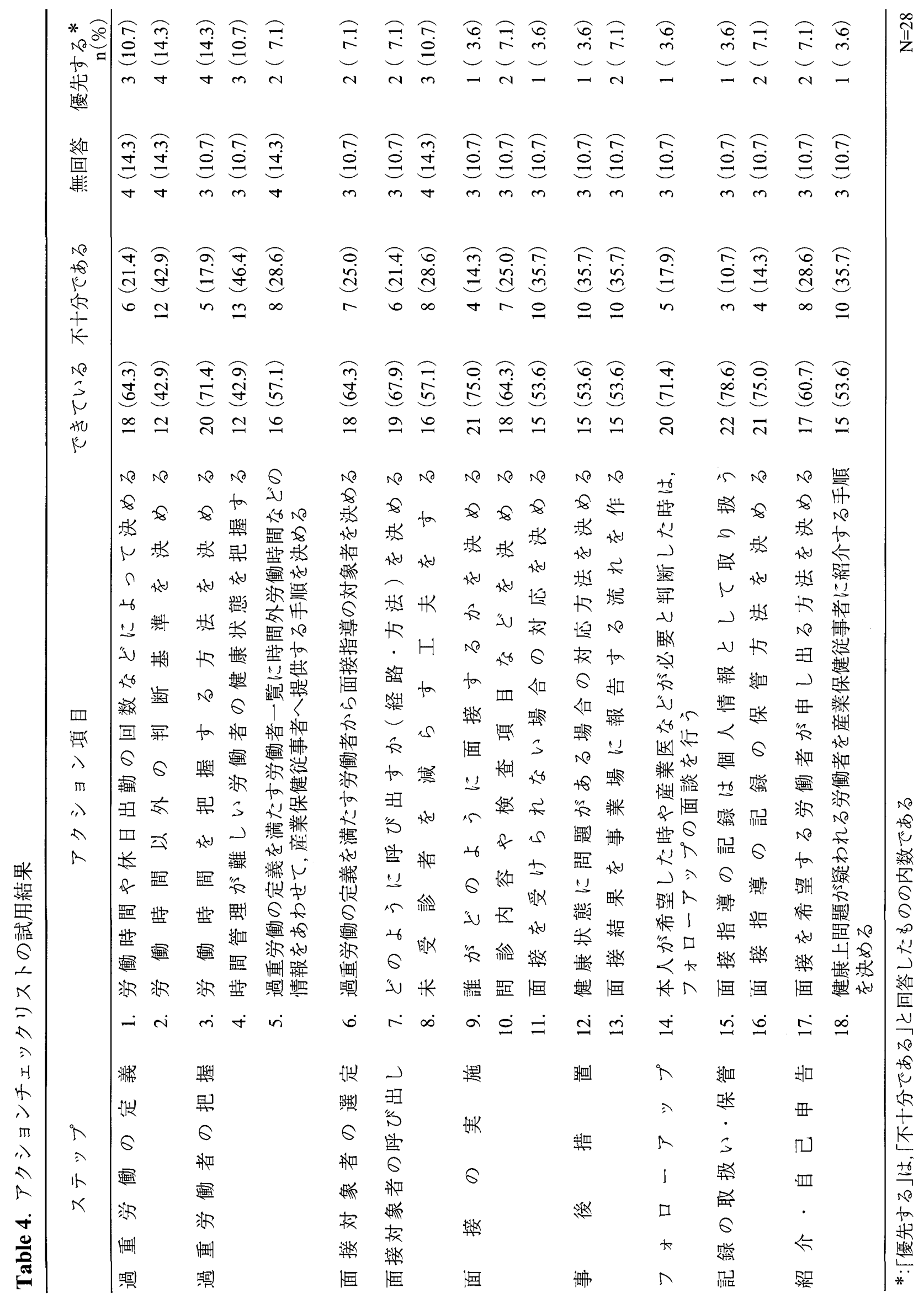


「時間管理が難しい労働者の健康状態を把握 する」(46.4\%)であった(Table 4).

\section{2. 介入調査}

第一回調査を回収できたところは19 事業 場 $(47.5 \%)$ ，第二回調査を回収できたところ

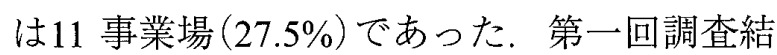

果をTable 5 にまとめた。9 事業場 $(47.4 \%)$ は 労働者数が50 人未満の小規模事業場であっ た。産業保健に関わる医療職が選任されてい る事業場は, 産業医で8 事業場 (42.1\%)，保健 師で2 事業場 (10.6\%)であった。面接指導の 実施状況は「対象者がいないので, 面接指導の 体制も準備していない」とする回答が10 事業

Table 5. 第一回介入調查結果

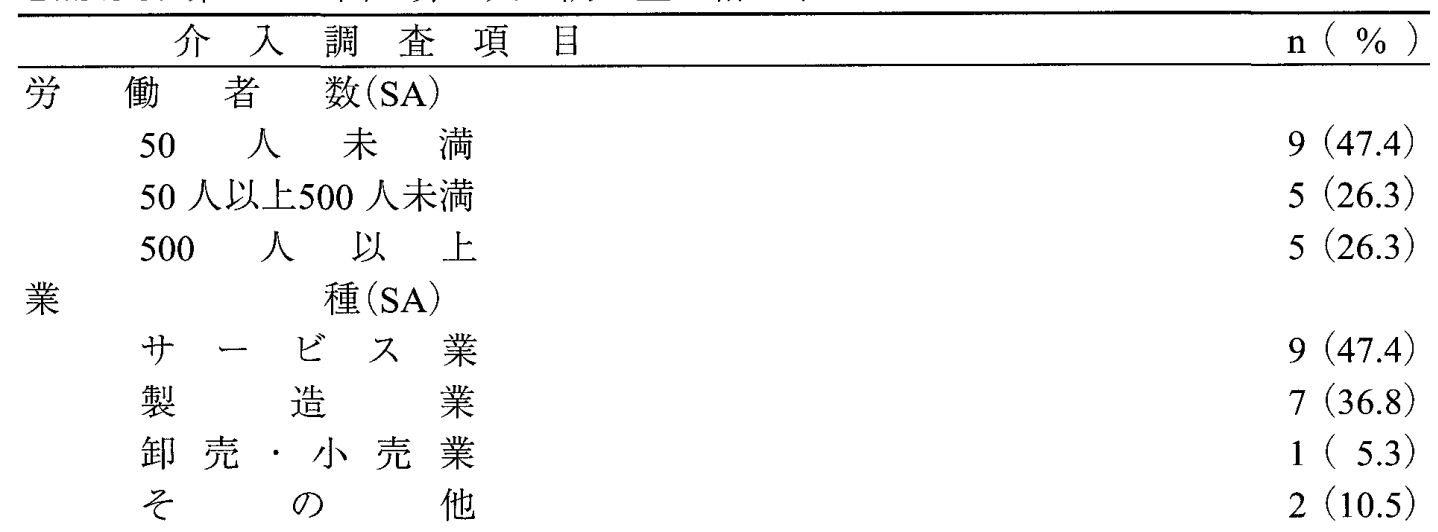

産業医の選任状況(SA)

$\begin{array}{lrr}\text { 常 } & \text { 勤 } & 2(10.5) \\ \text { 非 常 } & \text { 勤 } & 6(31.6) \\ \text { 選 } & \text { 任していない } & 11(57.9)\end{array}$

保健師の選任状況 (SA)

常勤

$1(5.3)$

非常勤

$1(5.3)$

選任していない

$17(89.5)$

面接指導の実施状況 (SA)

実 施している

対象者はいないが，面接指導の体制はある $3(15.8)$

対象者はいるが，実施していない

対象者がいないので, 面接指導の体制も準備していない $10(52.6)$

検 討 中である $2(10.5)$

平成 17 年安衛法改正により面接指導が義務化されたことを知って いるか (SA)

内容までよく理解している

内容までは理解していないが改正されたことは知っている

知 らなかった

無 答

$1(5.3)$

平成 20 年度より小規模事業場にも長時間労働者に対する面接指導 が義務化されることを知っているか (SA)

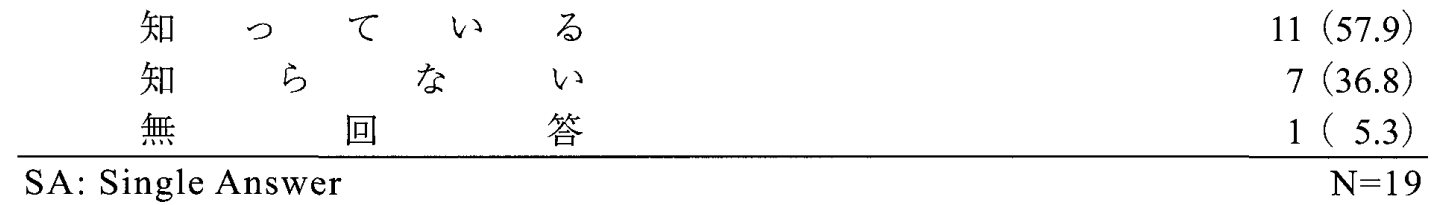


場 $(52.6 \%)$ ともっとも多かった. 長時間労働者 に対する面接指導の実施義務に関し, 平成 20 年 度より小規模事業場に適用されることをすで に知っているとする回答は, 11 事業場 (57.9\%) から得られた。

第一回調查および第二回調査ともに結果が 回収できた 11 事業場について, 介入群 $(8$ 事業 場) および非介入群 (3 事業場) に 分けて比較 したが,「面接指導の実施状況および体制の準 備状況」,「労働時間による面接指導などの対 象者の選定基準」「労働時間以外による面接 指導などの対象者の選定基準」および「面接指 導に準ずる措置の実施内容」のいずれの面接 指導の体制にも約一ヶ月間の介入期間におい て変化はみられなかった。

\section{考察}

アクションチェックリストは, 1996 年に国 際学働事務局 (ILO) および国際人間工学会 (IEA)により作成された人間工学チェックポ イントなどを端緒に, 産業保健の分野でも 種々のアクションチェックリストが開発され ている[5-7]. 今回, 我々は, アクションチェ ックリストの仕組みを利用して, 産業医など の産業保健専門職が選任されていない事業場 においても，事業場の衛生担当者によって効 果的な過重労働対策が確立できるよう開発さ れたACL $[3,4]$ を用い, 事業場の過重労働対策 にどのような影響を与えるか否かについて調 查を行った。

セミナー調査では, 過重労働対策をテーマ とするセミナーの教材としてACLを使用し， その有用性を評価した，ACLを介入したテー マは，新たに開発されたツールを用いたグル ープディスカッション形式で実施したため, 従来型の講義形式のセミナ一を期待した参加 者にとって悪い評価になる可能性も考え，三 つのテーマの有益性についてアンケートの結 果から比較を行ったが，それぞれに差はみら れなかった。このことからセミナー参加者に
とって,ACLを介入したテーマは, 従来型の講 義形式のテーマと同様の満足度が得られたも のと考えられた。

セミナーの参加者のうち約 8 割から, ACLに よって過重労働対策の体制作りのポイントが 理解でき，所属している事業場でも活用でき そうという回答が得られた。 また, セミナ一 への参加の目的が「事業場全体での活動推進 のため」とした参加者から高い評価が得られ たことから，特に組織の過重労働対策に関わ る職種にとって有用なツールとなる可能性が 示唆された。

過重労働対策上の仮想の事例に対する問題 点の抽出および改善案を提案させる作業では, $\mathrm{ACL}$ の使用後, それぞれの項目数が増加し, 特 に改善案においてACLの内容に準拠した提案 が認められたことから, ACLの利用により過 重労働対策のチェックが網羅的にできること 拈よびその解決方法を考えることができたと 思われた。

また, セミナー参加者の多くが衛生管理者 であったことから,ACLは産業医や産業看護 職以外の非医療職にとっても有用なツールと なり，産業保健に関わる医療職の選任率の低 い小規模事業場の衛生担当者にとっても役立 つと考えられた。

さらに, ACLを試用した結果では, 面接指導 の結果が多くの事業場で個人情報として管理 されていること, 面接指導の対象者を選定す るための労働時間や労働時間以外の基準の整 備が不十分であることが明らかになった。

ただし，セミナー調査では，セミナーの教材 として使用し, 評価を行ったため, 対照群を設 定できなかった，そこで,ACLが事業場の過 重労働対策に与える影響を正しく評洒するた めには，対照群を備えた研究デザインで介入 研究を行う必要があると考えられた。

介入調查では, ACLを用いて介入研究を実 施した。 アンケート回収およびデータ入力を 商工会議所の担当に依頼し, 回答事業場名を 匿名化したことにより事業場情報の取り扱い 
に配慮した。また, 担当者の段階では, 調查参 加事業場およびアンケートへの回答状況が把 握できるため，調查結果が回収できていない 事業場へは, 頻回に回収の督促を行い, 回収率 を高めるよう努めた。しかしながら，回収率 が47.5\%(第一回調査)，27.5\%(第二回調查) と 解析に十分な割合に達することができなかっ た原因の一つとして，郵送法またはFAXで行 った調查研究の限界である可能性があり，事 前報酬制度や調査の訪問留置など [7]による さらなる回収率の向上の努力や標本集団を増 やすことが必要であると考えられた，二つ目 の理由として, 調查空口を依頼した商工会議 所において事業場名が事実上判別されること を恐れた可能性が考えられた，研究者へのデ 一夕返却時には匿名化することをさらに強調 し，調查に協力しやすくする環境を整備する といった回収率を高める工夫が必要であった と考えられた。

平成20 年度の小規模事業場への面接指導 の実施義務化前の段階で実施した今回の調査 では, ACLが長時間労働者に対する面接指導 などの実施状況や体制に対して明らかな影響 はなかった。これは, 先に述べた回収率が低 かったため, 検定力が弱かったことが考えら れる他，次のようなことが原因として考えら れた。

まず, 法令の適用前であったため, 対象とな った事業場に面接指導の体制を確立させる意 欲が不十分であった可能性がある。次に， ACLを単純に配布したことおよび観察期間が 一ヶ月と短かったことから，事業場のアクシ ヨンに与える影響が小さくなってしまったこ とが考えられた。

また, ACLが事業場に与える影響は, 面接指 導の体制が未整備である事業場において体制 構築に役立つことおよび面接指導をすでに実 施している事業場においても体制の確諗や改 善に役立つことを調査前に想定していたため， 調査対象の絞り込みはあえて行わなかった。 しかし, 産業保健活動をより良く行うための
ツールとして開発されたACLは改善を目的と したツールであるため, 有効性が期待できる 対象は，改善を実施したいがその方法がわか らない場合または実施しているが効果が上が らない事業場であると考えられ，本調査では， 面接指導を「対象者はいるが実施していない」 または「検討中である」としているACLに対す るニーズが高いと思わ机る集団を多く集める 必要があった可能性がある。

総合して今回我々が実施した介入調査では, ACLの有用性は明らかにはならなかったもの の, セミナー調查の結果から，限定的ではある がACLの有用性が示唆された。 また, 介入調 查からは，実効的なツールとするためのヒン 卜を得ることができた。 したがって、ACLを 実効的なツールとして活用するためには， ACLなどのツールの利用による事業場の改善 のニーズが高い集団に対して，ツールの提供 を行うとともに専門職からの指導を加えるこ とが望ましいと考えられた。

平成 20 年度から産業保健の専門職が不在 の小規模事業場にも長時間労働者に対する面 接指導などが義務化され, 過重労働対策に関 する疑義は，地域産業保健センターに寄せら れることが予想される。ACLを地域産業保健 センターに配布し, 登録医より小規模事業場 に指導することで, 小規模事業場の過重労働 対策が有効に構築できると考えられ，平成20 年5 月現在, 全国の産業保健推進センターを 経由して広く配布を行っている。

\section{謝辞}

本研究は, 厚生労働科学研究費補助金労働 安全衛生総合研究事業「長時間労働および睡 眠等の関連要因と発生疾患との総合調查によ る効果的な過重労働対策の確立に関する研究 (H17 - 労働- 一般-001)」の成果の一部であ る. 


\section{引用 文 献}

1. 厚生労働省広島労働局 (2008): 企業における健康管理アンケートの実施結果. 広島労働局労 働基準部監督課, 広島 (http://www.hiroroudoukyoku.go.jp/)（2008 年5月26日）

2. 厚生労働省大臣官房統計情報部 (2008): 平成 19 年労働者健康状況調查の概況. 厚生労働 省大臣官房統計情報部賃金福祉統計課安全衛生第一係．東京 (http://www.mhlw.go.jp/toukei/ itiran/roudou/saigai/anzen/kenkou07/index.html)（2008 年10月10日）

3. 中尾智, 新見亮輔, 川瀬洋平, 堀江正知 (2008): 過重労働者の健康リスクマネジメントのため のアクションチェックリストの開発. JUOEH 30: 110

4. 中尾智, 堀江正知, 川瀬洋平 (2008): 産業医等による長時間労働者に対する面接指導のための 体制構築に関する研究. 健康開発 $12: 25-43$

5. 吉川徹, 川上憲人, 小木和孝, 堤 明純, 島津美由紀, 長見まき子, 島津明人 (2007): 職場環境改 善のためのメンタルヘルスアクションチェックリストの開発. 産業衛生学雑誌 49:127142

6. 湯淺晶子, 錦戸典子, 福田英子, 他 (2006): 元気職場づくりモデル事業の成果報告(その1) 支援 ッールとしてのアクションチェックリストの評価と改訂．産業衛生学雑誌 48:843

7. 川瀬洋平, 永野千景, 佐々木直子, 藤井ロナウド健蔵, 筒井隆夫, 堀江正知, 永田頌史 (2006): 過 重労働に伴う睡眠障害因子に関するアクションチェックリストの開発．JUOEH 28: 127

8. 萩原剛, 太田裕之, 藤井聡 (2006): アンケート調査回収率に関する実験研究 MM参加率の効 果的向上方策についての基礎的検討. 土木計画学研究 23: 117-123 
Use and Evaluation of Action Checklist for Health Risk Management of Employees Working Long Hours

Tomo NaKaO ${ }^{1,2}$, Yohei Kawase ${ }^{2,3}$, Ryosuke Shinmi ${ }^{2}$, Makiko Yamashita ${ }^{2}$, Akira Mitsuhashi ${ }^{4}$, Hanako FuKUdA ${ }^{5}$, Shoko KaWANAMI ${ }^{2}$, Hisanori Hiro ${ }^{6}$ and Seichi HorIE ${ }^{2}$

${ }^{1}$ Health Promotion Office, Personnel Department, ULVAC, Inc. Hagisono, Chigasaki, Kanagawa 253-8543, Japan

${ }^{2}$ Department of Health Policy and Management, Institute of Industrial Ecological Sciences, University of Occupational and Environmental Health, Japan. Yahatanishi-ku, Kitakyushu 807-8555, Japan

${ }^{3}$ Medical \& Occupatinal Health Center, Human Resources Department, Mitsubishi Chemical Corporation, Minato-ku, Tokyo 108-0014, Japan

${ }^{4}$ Human Resource Development Division, Health Promotion Department, Japan Industrial Safety \& Health Association, Japan. Minato-ku, Tokyo 108-0014, Japan

${ }^{5}$ Industrial Policy Division, The Tokyo Chamber of Commerce and Industry, Chiyoda-ku, Tokyo 100-0005, Japan

${ }^{6}$ Department of Mental Health, Institute of Industrial Ecological Sciences, University of Occupational and Environmental Health, Japan. Yahatanishi-ku, Kitakyushu 807-8555, Japan

Abstract : In Japan, the Industrial Safety and Health Law requires an employer to implement medical interviews for employees working long hours. The law stipulates the criteria of the targeted workers as those whose working time exceeds the legal limit of working hours, those with accumulated fatigue, and those who desire to receive an interview from a physician. Therefore, the employers should make an appropriate system to identify the workers who require a medical interview among employees working long hours with increasing health risks. In this study, we used "The Action Checklist for health risk management of employees working long hours (ACL)" and evaluated its efficacy. We conducted two studies: a seminar study, using ACL as an educational material in the seminar targeting occupational health professionals, and an interventional study, distributing materials with ACL in one group of small-scale enterprises and not in another group. In the seminar study, we observed a greater number of practical answers to the problems hypothetically set in the seminar among the occupational health professionals who used ACL. The results of a questionnaire given after the seminar revealed ACL was favorably accepted among $80 \%$ of all the participants in the seminar as "I have fully understood the usage of ACL" and "ACL seems to be useful in my workplace". In the interventional study, we could not see positive results from the distribution of $\mathrm{ACL}$, possibly because of the low response rate, short interventional term or distribution without individual explanation. Further investigation and efforts should be considered to widely diffuse ACL with individual explanations, to prevent health disorders caused or aggravated by working long hours.

Key words : long working hours, overwork, occupational health, action checklist. 